\title{
Sciendo
}

RURAL SUSTAINABILITY RESEARCH 44(339), 2020

ISSN - 2256-0939

(c) Latvia University of Life Sciences and Technologies, all rights reserved http://www.llu.lv/en/

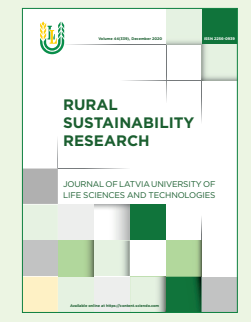

Received: 25 August 2020

Revised: 29 September 2020

Accepted: 12 October 2020

\section{The Novel Solution for Acid Whey Permeate Application in Animal Feeding}

\author{
Jana Lakstina ${ }^{1}$, Inese Aboltina ${ }^{2}$, Liga Vanaga ${ }^{3}$, \\ *Inga Ciprovica ${ }^{4}$, Daina Jonkus ${ }^{4}$, Jelena Zagorska ${ }^{4}$, Ingmars Cinkmanis ${ }^{4}$ \\ ${ }^{1} \mathrm{SC}$ Tukum hj9a piens, 7 Jelgavas street, Tukums, Latvia \\ ${ }^{2}$ Dairy laboratory Ltd., 1 Instituta street, Ulbroka, Stopinu region, Latvia \\ ${ }^{3}$ SC Livestock Experimental Station "Jaunpils", Jaunpils parish, Jaunpils, Latvia \\ ${ }^{4}$ Latvia University of Life Sciences and Technologies, 2 Liela street, Jelgava, Latvia
}

\begin{abstract}
The experiment was conducted to analyse the effect of fermented acid whey permeate on milk yield and composition in the lactating cows. Propionic acid bacteria and their metabolites have been used in the lactating cows feeding over decades, primarily to improve growth performance, feed conversation and milk production efficiency. Two groups of the lactating cows were arranged in the study: control group ( $\mathrm{n}=50)$ and experimental group $(n=50)$. Experimental group's animals received $0.5 \mathrm{~L}$ of fermented whey permeate daily. Acid whey permeate was inoculated with the freeze-dried PS-4 (Propionibacterium freudenreichii subsp. shermanii, Chr.Hansen, Denmark) starter and fermented anaerobically for 48 hours at $20 \pm 2{ }^{\circ} \mathrm{C}$. Fat, protein, lactose and total solids concentration in acid whey permeate and fermented acid whey permeate was analysed by the standard methods, but propionic acid was detected by HPLC. Milk composition and quality indices were determined at the beginning of the study and each month during 6 months period. At the end of the study the feeding of fermented acid whey permeate was stopped, but milk composition and quality data were monitored additionally after one month. Milk fat, protein, lactose, total solids, urea concentration and somatic cell count were analysed by a near infrared spectroscopy.

The variability in milk composition and quality data across trial was greater in the experiment group than in the control. Milk fat and somatic cell count were significantly different $(p<0.05)$ than other studied parameters in the experimental group cows' milk. Milk yield and lactose concentration were tended to increase during feeding of fermented acid whey permeate in the lactating cows without significant differences between control and experimental groups. Fermented acid whey permeate as feed supplement improves energy metabolism for dairy cows which results in the higher milk yield and fat concentration.
\end{abstract}

Key words: acid whey permeate, propionic acid, milk quality, cow feeding.

\section{Introduction}

Whey is a valuable by-product resulting from cheese and curd production. Whey consists of lactose, proteins, minerals, and fats as well as vitamins and organic acids. Whey composition differs depending on casein coagulation techniques used in cheese or curd production. There are two types of whey: sweet and acid. Sweet (cheese) whey consists of more fat and protein and in some cases also sodium and chlorides. Sweet whey $\mathrm{pH}$ is around of 5.9, but acid whey (obtained from curd production) characterises with higher minerals especially calcium and soluble salts, as well as lactic acid, and lower lactose concentration. Acid whey $\mathrm{pH}$ is around of 4.5-5.1 (Sarenkova, Ciprovica \& Cinkmanis, 2019). The application of both whey differs due to $\mathrm{pH}$ and minerals concentration. Acid whey has a more limited use for processing instead of sweet whey. An average composition of sweet and acid whey is demonstrated in Table 1.

\footnotetext{
* Corresponding Author's email: Inga.Ciprovica@1lu.lv
} 
Sweet and acid whey composition (Ozola \& Ciprovica, 2002)

\begin{tabular}{|l|c|c|c|c|c|c|}
\hline Whey & Total solids, $\%$ & Fat, $\%$ & Protein, $\%$ & Lactose, $\%$ & Salts, $\%$ & $\mathrm{pH}$ \\
\hline Sweet & $6.1-6.5$ & $0.1-0.4$ & 0.9 & 4.7 & 0.5 & $5.6-6.1$ \\
\hline Acid & 5.4 & 0.1 & 0.8 & 3.8 & 0.7 & $4.5-5.1$ \\
\hline
\end{tabular}

Whey has supplemented pig and other livestock feed for centuries (Anderson, Lamb \& Wiscombe, 1974), and the growth of farm modernisation systems has allowed more precisely to feed livestock animals.

Several methods are available for concentration of milk solids in cheese and curd production among them ultrafiltration. An application of ultrafiltration in cheese and curd production provides concentration of whey proteins into cheese and curd increasing outcome as well as a nutritional value of these products. Permeate, which is obtained during ultrafiltration, consists of mainly lactose and soluble salts, traces of protein and fat. Permeates, especially acid whey permeate, application is limited. Tightened environmental regulations forced the dairy industry to search for alternative solutions for whey streams (FAO, 2017).

Propionic acid bacteria are used in the production of Swiss-type cheese, silage and as probiotics in animal feeding (Piwowarek et al., 2018). Propionic acid bacteria and their metabolites have been used in the lactating cows feeding over decades, primarily to improve animals' growth performance, feed conversation and milk production efficiency (McAllister et al., 2011). Propionic acid bacteria are natural rumen microflora and produce propionic acid which is the main precursor for glucose production by the hepatic gluconeogenesis pathway (Azzaz et al., 2019). Propionic acid has prebiotic properties which stimulate the development of normal intestinal microflora (Radzikowski, 2018). The rumen microflora is a crucial in ruminant digestion as well as propionate fermentation in ruminants might lower methane emissions (Matthews et al., 2018; Chen et al., 2020).

The aim of the present study was to develop the solution for acid whey permeate application in animal feeding and to analyse the influence of fermented acid whey permeate on milk composition and quality in the lactating cows.

\section{Materials and Methods}

Fermented acid whey permeate production and quality evaluation during storage

Acid whey permeate (SC Tukuma piens) was used for the study. Acid whey permeate composition is summarized in Table 2.

Acid whey permeate $\mathrm{pH}$ was adjusted with $10 \% \mathrm{Na}_{2} \mathrm{CO}_{3}$ till 6.20 for providing the appropriate conditions for propionic acid bacteria growing. Acid whey permeate temperature was maintained at $20 \pm 2^{\circ} \mathrm{C}$ prior starter addition. Freeze-dried PS-4 (Propionibacterium freudenreichii subsp. shermanii, Chr. Hansen, Denmark) starter was added 0.02\% (w $\mathrm{v}^{-1}$ ) according to the starter producer recommendations and samples were fermented anaerobically for 48 hours at $20 \pm 2{ }^{\circ} \mathrm{C}$. Permeate composition (protein, fat, lactose, total solids, and propionic acid) and $\mathrm{pH}$ were measured after each 24 hours using standard methods and techniques. The final samples were kept at the same conditions for 72 hours analysing propionic acid concentration, $\mathrm{pH}$ and chemical composition after each 24 hours.

Feeding trial

The study was conducted from September 2019 until February 2020 in SC Livestock experimental station Jaunpils and SC Tukuma piens. Trial was carried out over 6 months' period. Two groups of lactating cows were arranged in the study: control $(\mathrm{n}=50)$ and experimental $(\mathrm{n}=50)$. Experimental group animals received $0.5 \mathrm{~L}$ of fermented whey permeate daily. Both groups of animals represented Holstein breed, received the same feed during the study, as well as animals were the first lactation, and an average lactation day was $133.00 \pm 22.19$ for experimental and $138.00 \pm 23.21$ for control group at the beginning of the trial. Basal diet consisted of ad-libitum total mixed ration: $10 \mathrm{~kg}$ water, $1.2 \mathrm{~kg}$ rapeseeds, $1.2 \mathrm{~kg}$ rapeseed meal, $1.8 \mathrm{~kg}$ soya flour, $5.0 \mathrm{~kg}$ flour, $1.8 \mathrm{~kg}$ grinded maize, $1.0 \mathrm{~kg}$ premix $(0.1 \mathrm{~kg}$ chalk, $0.06 \mathrm{~kg}$ salt,

Table 2

\section{An average acid whey permeate composition used in the study}

\begin{tabular}{|l|c|c|c|c|c|c|}
\hline Whey & Total solids, $\%$ & Fat, $\%$ & Protein, $\%$ & Lactose, $\%$ & Lactic acid, $\%$ & $\mathrm{pH}$ \\
\hline $\begin{array}{l}\text { Acid whey } \\
\text { permeate }\end{array}$ & $6.05 \pm 0.03$ & $0.05 \pm 0.00$ & $0.44 \pm 0.01$ & $4.94 \pm 0.03$ & $0.46 \pm 0.00$ & $4.53 \pm 0.18$ \\
\hline
\end{tabular}


$0.07 \mathrm{~kg}$ bulking soda, $0.4 \mathrm{~kg}$ Miramin Keragen ${ }^{\circledR}$, $0.3 \mathrm{~kg}$ Cellamin), $14.50 \mathrm{~kg}$ grass silage, $16.50 \mathrm{~kg}$ maize silage. The fermented whey permeate was added to the mixer prior feed distribution. Fermented acid whey permeate samples were prepared at SC Tukuma piens in an amount necessary for feeding trial and delivered to Jaunpils. Fermented whey permeate was kept at $20 \pm 2{ }^{\circ} \mathrm{C}$ for 72 hours at the station.

Individual milk samples were taken during morning milking, cooled immediately and transported to Dairy laboratory, Ltd. Milk composition and quality indices were determined at the beginning of the study and after each month during 6 months period. At the end of the study (29 February, 2020), the feeding of fermented acid whey permeate was stopped, but milk composition and quality data were additionally monitored only in the experimental group cows' milk after one month.

Methods of analysis

Fat, protein, lactose and total solids concentration in acid whey permeate and fermented acid whey permeate was analysed by MilkoScan ${ }^{\mathrm{TM}}$ Mars (Foss, Denmark) according to ISO 9622. Milk composition (fat, protein, lactose, total solids, urea concentration) was analysed using MilkoScan FT6000 (Foss, Denmark) according to ISO 9622 and somatic cell count (SSC) was determined using Fossomatic FC (Foss, Denmark) according to LVS EN ISO 13366-2.

$\mathrm{pH}$ was measured according to ISO 5546 using the $\mathrm{pH}$-meter Jenway (Barlword Scientific Ltd., UK). The electrode was calibrated with buffer solution $(\mathrm{pH}$ 4.00; 7.00).

Propionic acid was detected by HPLC. Around of $1.5 \mathrm{~mL}$ of clarified permeate sample was placed into sampler vials and sealed for HPLC analysis. Prominence HPLC system Shimadzu LC-20 (Torrance, CA, USA) was used for propionic acid analysis. Technical data: refractive index detector RID-10A; column SUPELCOSILLC-NH2 (250 mm x $4.6 \mathrm{~mm}) 5 \mu \mathrm{m} ; 35{ }^{\circ} \mathrm{C}$ temperature; gradient mobile phase acetonitrile: deionized water (80:20); volume of the injected sample $10 \mu \mathrm{L}$; flow rate $1.0 \mathrm{~mL} \mathrm{~min}^{-1}$ (Zolnere et al., 2018; Zolnere, Ciprovica, 2019).

All measurements were made into three replications. Data analysis

Statistical analysis was performed using a one-way of analysis of variance (ANOVA) and differences were considered statistically significant with a confidence level of $p<0.05$. The mean and the standard deviation of experimental data were calculated.

\section{Results}

Fermented acid whey production and quality control during 3 days of storage

The data on fermentation pattern of acid whey permeate are summarized in Table 3.

Lactic acid concentration in acid whey permeate varies from 0.459 to $0.468 \%$ (Table 2 ). $\mathrm{pH}$ of acid whey permeate was adjusted up to 6.19 prior fermentation but lactic acid salts remained in the substrate. Propionic acid bacteria have ability to convert glucose and lactic acid or lactates to propionic and acetic acids and lower amount of isovaleric, formic, succinic acids and carbon dioxide, etc. (Cogan, 2011). Propionic acid bacteria are able to metabolize lactic acid and lactates by the following equation (Cogan, 2011):

$$
\begin{gathered}
3 \text { mol lactate }=2 \mathrm{~mol} \text { propionate }+1 \text { mol acetate }+ \\
1 \mathrm{~mol} \mathrm{CO}_{2}+1 \mathrm{~mol} \mathrm{ATP}(1)
\end{gathered}
$$

This theoretical calculation conflicts with our data; we established a very low propionic acid concentration due to a slow propionic acid bacteria growing in the fermentation substrate as well as a low $\mathrm{pH}$ after 24 and 48 hours of fermentation. The optimal $\mathrm{pH}$ of propionic acid bacteria is around 7 (range 4.5-8.0) in which they showed the ability to produce propionic acid (Piwowarek et al., 2018).

Strains of Propionibacterium freudenreichii subsp. shermanii are able to metabolize lactose (Piwowarek

Table 3

The changes of acid whey permeate composition and quality indices during fermented acid whey permeate production

\begin{tabular}{|l|c|c|c|}
\hline \multicolumn{1}{|c|}{ Indices } & Initial & After 24 h of fermentation & After 48 h of fermentation \\
\hline Total solids, $\%$ & $6.02 \pm 0.00$ & $5.89 \pm 0.01$ & $5.58 \pm 0.00$ \\
\hline Fat, $\%$ & $0.05 \pm 0.00$ & $0.05 \pm 0.00$ & $0.05 \pm 0.00$ \\
\hline Protein, $\%$ & $0.43 \pm 0.01$ & $0.67 \pm 0.00$ & $0.70 \pm 0.00$ \\
\hline Lactose, \% & $4.92 \pm 0.00$ & $4.71 \pm 0.00$ & $4.64 \pm 0.00$ \\
\hline Propionic acid, mg L $^{-1}$ & n.d. $*$ & $16.62 \pm 0.90$ & $76.62 \pm 1.00$ \\
\hline pH & $6.19 \pm 0.00$ & $5.69 \pm 0.01$ & $4.81 \pm 0.01$ \\
\hline
\end{tabular}

*not determined 
Table
urs of

The changes of fermented acid whey permeate composition and quality indices during 72 hours of storage at ambient temperature

\begin{tabular}{|l|c|c|c|c|}
\hline \multicolumn{1}{|c|}{ Indices } & $\begin{array}{c}\text { Fermented } \\
\text { permeate }\end{array}$ & $\begin{array}{c}\text { After 24 h of } \\
\text { storage }\end{array}$ & $\begin{array}{c}\text { After 48 h of } \\
\text { storage }\end{array}$ & $\begin{array}{c}\text { After } 72 \mathrm{~h} \text { of } \\
\text { storage }\end{array}$ \\
\hline Total solids, \% & $5.58 \pm 0.00$ & $4.30 \pm 0.01$ & $4.30 \pm 0.00$ & $4.28 \pm 0.00$ \\
\hline Fat, $\%$ & $0.05 \pm 0.00$ & $0.05 \pm 0.00$ & $0.05 \pm 0.00$ & $0.05 \pm 0.00$ \\
\hline Protein, \% & $0.70 \pm 0.00$ & $0.70 \pm 0.00$ & $0.70 \pm 0.00$ & $0.71 \pm 0.00$ \\
\hline Lactose, \% & $4.64 \pm 0.00$ & $3.37 \pm 0.00$ & $3.37 \pm 0.00$ & $3.38 \pm 0.00$ \\
\hline Propionic acid, $\mathrm{mg} \mathrm{L}^{-1}$ & $76.62 \pm 1.00$ & $115.58 \pm 1.28$ & $270.20 \pm 1.99$ & $308.58 \pm 2.89$ \\
\hline pH & $4.81 \pm 0.01$ & $4.66 \pm 0.01$ & $4.64 \pm 0.01$ & $4.62 \pm 0.01$ \\
\hline
\end{tabular}

et al., 2018) and with this finding we could explain decreasing lactose concentration during fermentation. Permeate contains also lactic acid bacteria which pass into whey during curd production and continue growth in the substrate. Extensive accumulation of fermentation by-products lowers $\mathrm{pH}$, mainly acetic acid and lactic acid, and inhibits the growth of propionic acid bacteria and correspondingly propionic acid production. We also observed the increasing of protein concentration during fermentation. It could be explained with biomass formation during fermentation.
According to the study of Blanc and Goma (1987), the amount of biomass production varied from 1.7 to $78 \mathrm{~g} \mathrm{~L}^{-1}$. During first 24 hours of fermentation the biomass production reached $2.4 \mathrm{~g} \mathrm{~L}^{-1}$, after 48 hours it was only $0.3 \mathrm{~g} \mathrm{~L}^{-1}$. Interestingly, that protein concentration remained invariable during 72 hours of fermented acid whey permeate storage (Table 4); however, propionic acid concentration increased multiple times.

During fermentation and fermented acid whey permeate storage we ensured the appropriate $\mathrm{pH}$ for

The effect of infusion of fermented acid whey permeate on milk yield and composition

\begin{tabular}{|c|c|c|c|c|c|c|}
\hline Samples & Milk yield, kg & Fat, \% & Protein, $\%$ & $\mathrm{SSC}, \log _{10} \mathrm{~mL}^{-1}$ & Lactose, $\%$ & Urea, $\mathrm{mg} \mathrm{dL}^{-1}$ \\
\hline \multicolumn{7}{|c|}{ Control } \\
\hline Initial & $36.61 \pm 7.03^{\mathrm{a}}$ & $3.82 \pm 0.72^{\mathrm{a}}$ & $3.14 \pm 0.20^{\mathrm{a}}$ & $4.42 \pm 0.51^{\mathrm{a}}$ & $5.06 \pm 0.10^{\mathrm{a}}$ & $30.61 \pm 4.68^{a}$ \\
\hline after 1 month & $31.91 \pm 9.01^{\mathrm{a}}$ & $3.50 \pm 0.70^{\mathrm{a}}$ & $3.21 \pm 0.55^{\mathrm{a}}$ & $4.91 \pm 0.56^{\mathrm{a}}$ & $4.87 \pm 0.77^{\mathrm{a}}$ & $34.02 \pm 6.35^{\mathrm{a}}$ \\
\hline after 2 months & $36.00 \pm 6.02^{\mathrm{a}}$ & $3.29 \pm 0.61^{\mathrm{a}}$ & $3.36 \pm 0.24^{\mathrm{a}}$ & $4.93 \pm 0.53^{\mathrm{a}}$ & $4.96 \pm 0.14^{\mathrm{a}}$ & $32.73 \pm 4.48^{\mathrm{a}}$ \\
\hline after 3 months & $35.67 \pm 2.46^{\mathrm{a}}$ & $3.14 \pm 0.99^{a}$ & $3.13 \pm 0.07^{\mathrm{a}}$ & $4.97 \pm 0.59^{\mathrm{a}}$ & $4.92 \pm 0.10^{\mathrm{a}}$ & $37.23 \pm 6.45^{\mathrm{a}}$ \\
\hline after 4 months & $33.61 \pm 6.33^{\mathrm{a}}$ & $3.52 \pm 0.96^{\mathrm{a}}$ & $3.46 \pm 0.40^{\mathrm{b}}$ & $5.23 \pm 0.67^{\mathrm{a}}$ & $4.94 \pm 0.21^{\mathrm{a}}$ & $32.92 \pm 5.17^{\mathrm{a}}$ \\
\hline after 5 months & $29.79 \pm 7.77^{\mathrm{a}}$ & $3.46 \pm 0.88^{\mathrm{a}}$ & $3.42 \pm 0.48^{\mathrm{a}}$ & $5.25 \pm 0.63^{\mathrm{a}}$ & $4.89 \pm 0.58^{b}$ & $32.34 \pm 6.46^{\mathrm{a}}$ \\
\hline after 6 months & $29.56 \pm 7.26^{\mathrm{a}}$ & $3.71 \pm 0.82^{\mathrm{a}}$ & $3.45 \pm 0.24^{\mathrm{a}}$ & $5.29 \pm 0.64^{\mathrm{a}}$ & $4.95 \pm 0.15^{\mathrm{a}}$ & $27.34 \pm 6.22^{\mathrm{a}}$ \\
\hline Average & $32.42 \pm 7.80^{\mathrm{a}}$ & $3.53 \pm 0.63^{a}$ & $3.37 \pm 0.30^{\mathrm{a}}$ & $5.12 \pm 0.63^{a}$ & $4.96 \pm 0.10^{\mathrm{a}}$ & $31.91 \pm 5.80^{\mathrm{a}}$ \\
\hline \multicolumn{7}{|c|}{ Experimental } \\
\hline Initial & $35.90 \pm 6.89^{\mathrm{a}}$ & $3.51 \pm 0.58^{\mathrm{a}}$ & $3.09 \pm 0.19^{\mathrm{a}}$ & $4.99 \pm 0.55^{\mathrm{a}}$ & $5.05 \pm 0.16^{\mathrm{a}}$ & $28.32 \pm 5.45^{\mathrm{a}}$ \\
\hline after 1 month & $33.57 \pm 6.20^{\mathrm{a}}$ & $3.43 \pm 0.48^{\mathrm{a}}$ & $3.26 \pm 0.25^{\mathrm{b}}$ & $4.87 \pm 0.54^{\mathrm{a}}$ & $5.01 \pm 0.17^{\mathrm{a}}$ & $33.78 \pm 4.64^{\mathrm{a}}$ \\
\hline after 2 months & $35.13 \pm 5.25^{\mathrm{a}}$ & $3.48 \pm 0.75^{\mathrm{a}}$ & $3.37 \pm 0.20^{\mathrm{a}}$ & $5.02 \pm 0.56^{\mathrm{a}}$ & $4.95 \pm 0.15^{\mathrm{a}}$ & $31.67 \pm 4.34^{\mathrm{a}}$ \\
\hline after 3 months & $36.34 \pm 8.34^{\mathrm{a}}$ & $3.27 \pm 0.56^{\mathrm{a}}$ & $3.12 \pm 0.15^{\mathrm{a}}$ & $4.78 \pm 0.49^{\mathrm{a}}$ & $4.96 \pm 0.23^{\mathrm{a}}$ & $31.22 \pm 2.32^{\mathrm{a}}$ \\
\hline after 4 months & $33.98 \pm 7.61^{\mathrm{a}}$ & $3.38 \pm 0.39^{b}$ & $3.41 \pm 0.24^{\mathrm{a}}$ & $4.48 \pm 0.42^{b}$ & $4.98 \pm 0.17^{\mathrm{a}}$ & $32.69 \pm 5.37^{\mathrm{a}}$ \\
\hline after 5 months & $29.58 \pm 8.82^{\mathrm{a}}$ & $3.61 \pm 0.67^{\mathrm{a}}$ & $3.47 \pm 0.30^{\mathrm{b}}$ & $4.95 \pm 0.43^{b}$ & $4.95 \pm 0.15^{\mathrm{a}}$ & $33.97 \pm 5.75^{\mathrm{a}}$ \\
\hline after 6 months & $28.78 \pm 8.09^{\mathrm{a}}$ & $3.79 \pm 0.63^{\mathrm{a}}$ & $3.47 \pm 0.23^{\mathrm{a}}$ & $5.14 \pm 0.52^{\mathrm{a}}$ & $4.95 \pm 0.15^{\mathrm{a}}$ & $28.66 \pm 6.35^{\mathrm{a}}$ \\
\hline Average & $33.23 \pm 7.90^{\mathrm{a}}$ & $3.54 \pm 0.80^{b}$ & $3.34 \pm 0.28^{a}$ & $4.57 \pm 0.52^{b}$ & $4.98 \pm 0.16^{a}$ & $31.53 \pm 5.66^{a}$ \\
\hline
\end{tabular}

\footnotetext{
a,b Means with the same column followed by different letter differ at $\mathrm{p}<0.05$
} 
propionic acid bacteria growing which resulted in the increasing concentration of propionic acid up to $308.58 \mathrm{mg} \mathrm{L}^{-1}$. According to the findings of Blanc and Goma (1987), the batch method that uses a variety of substrates typically produces $1-3 \%$ propionic acid in 7 to 14 days.

Feeding trial

The impact of feeding of propionic acid bacteria and propionic acid on the performance of lactating cows had been evaluated previously (Azzaz et al., 2019), but results were inconsistent due to many factors involved: bacteria strain, bacteria viability, diet, frequency of feeding, animal status, breed, age, health and physical condition.

Current experiment was conducted to analyse the effect of fermented acid whey permeate containing propionic acid bacteria and propionic acid on milk yield and composition in lactating cows. The study results are summarized in Table 5.

Milk yield and lactose concentration were tended to increase during feeding of fermented acid whey permeate in lactating cows without significant differences between control and experimental groups. The enzymes involved in the gluconeogenesis pathway convert propionic acid into glucose. The concentration of available glucose increases and this leads to an increase lactose, too. Lactose is an osmotic regulator of milk production and causes an increase of water in the lumen and thus, an increase of milk production (Azzaz et al., 2019). With these findings we could explain small differences in milk yield and lactose data in the experimental group cows' milk.

Milk fat and somatic cell count results were significantly different $(p<0.05)$ than other studied parameters in the experimental group cows' milk comparing with the control group. Results from propionic acid infusion in the literature lead to an increase of milk yield and protein concentration, and a decrease of fat concentration when mean doses were infused and no effect on milk yield when great doses were infused (Sheperd \& Combs, 1998; Rigout et al., 2003). This finding conflicts with our data; we observed the higher fat content $(\mathrm{p}=0.002)$ in the experimental group animals' milk which could be explained with the higher concentration of volatile fatty acids in the rumen, as well as the ratio of acetic acid to propionic acid influences milk fat secretion. Large amount of volatile fatty acids is produced in the rumen by fermentation of feed carbohydrates. A lot of energy has to be provided by diet in the form of propionic acid in the rumen (Scientific opinion, 2011; Rigout et al., 2003). The amount of propionic acid produced during ruminal fermentation of feed ranges from 61 to $196 \mathrm{~g} \mathrm{~kg}^{-1}$ feed dry matter (Scientific opinion, 2011). According to EFSA opinion, propionic acid concentration in feed as a food additive for livestock should not exceed $0.1-40 \mathrm{~g} \mathrm{~kg}^{-1}$ feed (Scientific opinion, 2011). Urea concentration was also decreased; however, no difference $(\mathrm{p}=0.68)$ between control and experimental groups has been highlighted in the tested parameter.

The reports of De Ondarza and Seymour (2008) and Weiss, Wyatt and McKelvey (2008) established that the effect of Propionibacterium spp. had been found in the experiments with lactating cows using Propionibacterium acidipropionici strain P169, which increased the efficiency of milk production. With regard to literature results (Rigout et al., 2003, Seo et al., 2010; Lehloenya et al., 2008; Weiss, Wyatt \& McKelvey, 2008; Raeth-Knight, Linn \& Jung, 2007; Stein et al., 2006), the effect of infusion of propionic acid in the rumen has led to inconsistent results on milk production and seems to have similar effect on milk composition. However, propionic acid is the main energy source for growth of cow.

The variability in milk composition and quality data across trial was greater in the experimental than in the control group. This may reflect day-to-day differences in the rumen microbiome or inconsistent propionic acid concentration during a feeding trial. We observed a reduction in the urea concentration during feeding trial, which indicated to higher feed components utilisation rate.

We also examined milk quality and composition data after one month of the feeding trial interruption (Table 6).

The results showed significant differences $(\mathrm{p}<0.05)$ in protein concentration and somatic cell

Theble 6 trial interruption

\begin{tabular}{|l|c|c|c|c|c|c|}
\hline \multicolumn{1}{|c|}{ Samples } & Milk yield, $\mathrm{kg}$ & Fat, \% & Protein, $\%$ & $\mathrm{SSC}, \log _{10} \mathrm{~mL}^{-1}$ & Lactose, $\%$ & $\mathrm{Urea}^{\mathrm{mg} \mathrm{dl}}{ }^{-1}$ \\
\hline $\begin{array}{l}\text { at the end of } \\
\text { experiment }\end{array}$ & $28.78 \pm 8.09^{\mathrm{a}}$ & $3.79 \pm 0.63^{\mathrm{a}}$ & $3.47 \pm 0.23^{\mathrm{a}}$ & $5.14 \pm 0.52^{\mathrm{a}}$ & $4.95 \pm 0.15^{\mathrm{a}}$ & $28.66 \pm 6.35^{\mathrm{a}}$ \\
\hline after 1 month & $28.53 \pm 6.93^{\mathrm{a}}$ & $3.86 \pm 0.69^{\mathrm{a}}$ & $3.44 \pm 0.32^{\mathrm{b}}$ & $4.75 \pm 0.50^{\mathrm{b}}$ & $4.93 \pm 0.16^{\mathrm{a}}$ & $31.44 \pm 6.19^{\mathrm{a}}$ \\
\hline
\end{tabular}

a,b Means with the same column followed by different letters differ at $\mathrm{p}<0.05$ 
count. We could explain these changes with unstable microbial population in the host which may have caused variability in rumen fermentation and in milk yield and composition.

\section{Conclusions}

This research has shown the possibility to the application of acid whey permeate on a commercial scale for feed supplements production using propionic acid bacteria.

Increasing propionic acid concentration in feed positively influences glucose supply to mammary gland, correspondingly, lactose production efficiency, and significantly lower somatic cell count in milk.

\section{References}

Anderson, M.J., Lamb, C.H., Wiscombe, R.L. (1974). Feeding liquid whey to dairy Cattle. Journal of Dairy Science, 57 (10), 1206-1210.

Azzaz, H.H., Mohamed El-Sherbiny, Murad, H.A., Ebeid, H.M. (2019). Propionibacteria in ruminant's diets: An overview. Journal of Applied Science, 19, 166-172.

Blanc, P., Goma, G. (1987). Propionic acid and biomass production using continuous ultrafiltration fermentation of whey. Biotechnology Letters, 11, 189-194.

Chen, J., Harsted, O.M., McAllister, T., Dorsch, P., Holo, H. (2020). Propionic acid bacteria enhance ruminal feed degradation and reduce methane production in vitro. Acta Agriculturae Scandinavica, Section A-Animal Science, DOI:1 0.10800/09064702.2020.1737215

Cogan, T.M. (2011). Microbiology of cheese. In H. Roginski, J.W. Fuquay, P.F. Fox (eds.), Encyclopaedia of Dairy Science (pp. 625-631). Academic Press.

De Ondarza, M.B., Seymour, W.M. (2008). Case study: Effect of propionibacteria supplementation on yield of milk and milk components of dairy cows. The Professional Animal Scientist, 24, 254-259.

FAO (2017). The future of food and agriculture. Trends and challenges. Rome: FAO.

Lehloenya, K.V., Krehbiel, C.R., Mertz, K.J., Rehberger, T.G., Spicer, L.J. (2008). Effects of propionibacteria and yeast culture feed to steers on nutrient intake and site and extent of digestion. Journal of Dairy Science, 91, 653-662.

Matthews, C., Crispie, F., Lewis, E., Reid, M., O’Toole, P.W., Cotter, P.D. (2019). The rumen microbiome: a crucial consideration when optimising milk and meat production and nitrogen utilisation efficiency. Gut Microbes, 10 (2), 155-132. DOI: 10.1080/19490976.2018.1505176
McAllister, T.A., Beauchemin, K.A., Alazzeh, A.Y., Baah, J., Teather, R.M., Stanford, K. (2011). Review: The use of direct fed microbials to mitigate pathogens and enhance production of cattle. Canadian Journal of Animal Science, 91, 193-211.

Ozola, L., Ciproviča, I. (2002). Piena pārstrādes tehnologijas (Dairy processing technology). Jelgava: Latvia University of Agriculture, 248 lpp. (In Latvian)

Piwowarek, K., Lipinska, E., Hoe-Szymanczuk E., Lieliszek, M., Scibisz, I. (2018). Propionibacterium spp. - source of propionic acid, vitamin $\mathrm{B}_{12}$ and other metabolites important for the industry. Applied Microbiology and Biotechnology, 102 (2), 515-538.

Radzikowski, K. (2018). The effects of using technological additives in feeding farm animals. World Scientific News, 106 (2018), 46-56.

Raeth-Knight, M.L., Linn, J.G., Jung, H.G. (2007). Effect of direct-fed microbials on performance, diet digestibility, and rumen characteristics of Hilstein cows. Journal of Dairy Science, 90, 1802-1809.

Rigout, S., Hurtaud, C., Lemosquet, S., Bach, A., Rulquin, H. (2003). Lactational effect of propionic acid and duodenal glucose in cows. Journal of Dairy Science, 86, 243-253.

Sarenkova, I., Ciprovica, I., Cinkmanis, I. (2019). The effect of concentrated whey solids on lactobionic acid production by Pseudomonas taetrolens. In FoodBalt: $13^{\text {th }}$ Baltic conference on food science and technology "Food. Nutrition. Well-being.”, 2-3 May 2019 (pp. 250-253). Jelgava: Latvia University of Life Sciences and technologies.

Scientific opinion (2011). Scientific Opinion on the safety and efficacy of propionic acid, sodium propionate, calcium propionate and ammonium propionate for all animal species. EFSA Journal, 9(12), 2446.

Seo, J.K., Kim, S.W., Kim, M.H., Upadhaya S.D., Kam, D.K., Ha, J.K. (2010). Direct-fed microbials for ruminant animals. Asian-Australian Journal of Animal Sciences, 23, 1657-1667.

Sheperd, A.C., Combs, D.K. (1998). Long-term effects of acetate and propionate on voluntary feed intake by midlactation cows. Journal of Dairy Science, 81, 2240-2250.

Stein, D.R., Allen, D.T., Perry, E.B., Bruner, J.C., Gates, K.W., Rehberger, T.G., Mertz, K., Jones, D., Spicer, J. (2006). Effects of feeding propionibacteria to dairy cows on milk yield, milk components, and reproduction. Journal of Dairy Science, 89, 111-125. 
Weiss, W.P., Wyatt D.J., McKelvey T.R. (2008). Effect of feeding propionibacteria on milk production by early lactation dairy cows. Journal of Dairy Science, 91, 646-652.

Zolnere, K., Ciprovica (2019). Lactose hydrolysis in different solids content whey and whey permeate. In FoodBalt: $13^{\text {th }}$ Baltic conference on food science and technology "Food. Nutrition.
Well-being.", 2-3 May 2019 (pp. 35-39). Jelgava: Latvia University of Life Sciences and Technologies.

Zolnere, K., Ciprovica, I., Kirse, A., Cinkmanis, I. (2018). A study of commercial $\beta$ galactosidase stability under simulated in vitro gastric conditions. Agronomy research, 16(S2), 15551562 .

\section{Acknowledgements}

The study was supported by the Agriculture and Rural Support Service of the Republic of Latvia project No. 18-00-A01612-000012 "Novel solutions for milk products and their processing by-products production". 